\title{
Applications of Compliance to Cost Ratio (C-CR) Analysis in the Determination of Optimum Mix of Insulating Bricks in Masonry
}

\author{
Davies Oladayo Folorunso*, Abayomi Adewale Akinwande \\ Department of Metallurgical and Materials Engineering, The Federal University of Technology, Akure, Ondo State, Nigeria \\ Email: *dofolorunso@futa.edu.ng
}

How to cite this paper: Folorunso, D.O. and Akinwande, A.A. (2021) Applications of Compliance to Cost Ratio (C-CR) Analysis in the Determination of Optimum Mix of Insulating Bricks in Masonry. Journal of Minerals and Materials Characterization and Engineering, 9, 134-147.

https://doi.org/10.4236/jmmce.2021.92010

Received: June 26, 2020

Accepted: March 6, 2021

Published: March 9, 2021

Copyright $\odot 2021$ by author(s) and Scientific Research Publishing Inc. This work is licensed under the Creative Commons Attribution International License (CC BY 4.0).

http://creativecommons.org/licenses/by/4.0/

(c) (i) Open Access

\begin{abstract}
The scarcity of housing increases as population continues to rise all over the world. Despite government efforts at providing houses, yearly demand keeps on exceeding available houses and hence the hike in rent, the cost of erecting houses and the cost of building materials. This ultimately calls for a decisive solution. This study therefore applied compliance to cost ratio (C-CR) analysis in evaluating the optimum properties of fired ceramic bricks. The optimum mix proportions of waste glass (WG) and wood saw dust (WSD) in fired bricks, that will be suitable for housing constructions were hence determined. Fired clay brick samples which contained varied proportions of WG and WSD were examined for physical, mechanical and thermal properties in line with standard procedures. The results were compared with existing standards and property evaluation index, compliance level and C-CR were applied in analyzing the results obtained. It was observed that with increasing WG content, compliance level increased. Also, cost ratio and experimental cost of each brick sample trended upward. Sample with mix proportion; $20 \mathrm{wt} \% \mathrm{WG}, 5 \mathrm{wt} \% \mathrm{WSD}$ and $75 \mathrm{wt} \%$ clay had compliance level of $94 \%$ and C-CR index of 7.81, hence chosen as optimum mix proportion for masonry bricks.
\end{abstract}

\section{Keywords}

Properties Evaluation, Housing, Fired Clay Bricks, Compliance to Cost Ratio (C-CR) and Masonry

\section{Introduction}

Housing and shelter remain very important needs of man. As population continues to rise all over the world, scarcity of housing increases which requires a 
solution. Despite government interventions in providing houses, yearly demand keeps on exceeding available houses [1] [2] [3]. Migration from rural areas to cities has led to population explosion in the cities, leading to soaring demands for few houses available [4] [5]. Since demand for houses is more than the available houses, rent keeps going up and remains unaffordable for the common man. Housing provision in rural areas can help reduce migration from rural areas to cities and this in turn will lower the pressure on basic amenities in the urban areas [4] [6].

This insufficiency is a result of some factors, one of which is the high cost of building materials like ordinary Portland cement (OPC), commonly used in making Sandcrete bricks in modern day masonry as claimed in [7] [8] [9]. Works have been done in using clay bricks as alternative building bricks since clay has good workability, it is relatively cheap and readily available in our immediate environment [10] [11]. The use of this clay is cost-effective and energy saving [10] [12]. Many researchers have utilized environmental wastes in the production of bricks by adding these wastes to clay. Environmental wastes used include wood saw dust [13] and ashes [14], bamboo ashes [15], rice husk [16], charcoal [17], sludge [18] [19], waste glass [20] [21], fly ash [22], coal mining and petroleum refining wastes [19] [23]. These wastes were added to improve properties of fired bricks for various applications ranging from masonry to refractory [24] [25].

In a bid to reduce indoor temperature which is high on sunny days (occasioned by global warming), insulating bricks are needed [26]. These insulating bricks can also be employed in the construction of low cost houses towards reducing housing deficits. Thus, this particular bricks should be affordable, and readily available even for massive housing construction. To obtain these kinds of bricks, additives such as wood saw dust, as employed in this study can be utilized in the course of production. Wood saw dust had been known to improve insulating efficiency of bricks by creating pores which serve as air trap, thereby reducing thermal conduction in bricks [13] [14] [27] [28] [29]. Nevertheless, increased saw dust in bricks results in reduced strength and bulk density [27] [28] and this is detrimental to the durability of the bricks. Incorporation of waste glass was recorded to improve some strength properties of fired bricks [21] [30], so as to improve their load bearing capacity. Thus, incorporation of these additives (in varied proportions) namely wood saw dust and waste glass into fired bricks was studied and the compliance to cost implication analyzed by applying C-CR.

Various studies accounted for the properties and influence of waste addition on the properties of bricks. However, there is little account for compliance of such bricks with existing standards. There was no evaluation of the compliance level of the bricks samples with respect to the experimental cost incurred in producing the samples. This study, therefore, involved selection of optimum mix proportions for fired ceramic bricks containing waste glass and wood saw dust additives using Compliance to Cost Ratio (C-CR) analysis as developed in [31]. $\mathrm{C}-\mathrm{CR}$ examines the influence of the properties with respect to the cost incurred 
on compositions employed in the course of sample preparation, and provides a way of selecting mix proportion of compositions for a given application, putting into consideration level of compliance with existing standards. Cost ratio on its own, evaluates in details, the cost of all components involved in the laboratory preparation of samples. It gives a view of cost of production of each sample at experimental and industrial scale. In general, C-CR helps to analyze for the optimum sample/mix proportion at experimental and industrial scale by accounting for the compliance level of each sample to existing standards and cost ratio of the compositions present in each sample, allotting price value to every material used. C-CR values are dependent on costs of compositions, values of properties after carrying out tests on samples and categories of samples produced. These values vary from one experiment to another and dependent of cost of materials and cost incurred during production process. Optimal mix proportion for masonry bricks is identified by ranking based on $\mathrm{C}-\mathrm{CR}$ value and the one with the highest C-CR is ranked first.

In carrying out $\mathrm{C}-\mathrm{CR}$ analysis, the following steps were taken:

1) recording the value of properties obtained during tests;

2) obtaining the standard values for properties of masonry brick;

3 ) evaluating the property evaluation index and total value under each sample;

4) estimating the compliance level for each sample;

5) evaluating experimental cost of each sample;

6) accessing the Cost Ratio CR for each composition and Total Cost Ratio (TCR) of each sample and;

7) evaluating for the Compliance to Cost ratio (C-CR curve) as stated in Equation (3).

However, the purposes are to:

1) ensure the production of the samples and ultimately, the bricks at the cheapest costs possible;

2) ensure strict compliance with the standard procedures;

3) assess the samples alongside the costs in order to select the sample with the optimum cost and;

4) determine, eventually, the sample with the best compliance to cost ratio.

\section{Materials and Methods}

The materials used were clay, waste glass (WG) and wood saw dust (WSD). 600 $\mathrm{Kg}$ of clay (excavated from Ijapo clay hill in Akure, Ondo State, Nigeria) was bought at $\mathrm{N} 6.77 / \mathrm{kg}$; while $90 \mathrm{Kg}$ of WSD was procured at $\mathrm{N} 1.87 / \mathrm{Kg}$. Glass wastes were also acquired at $\mathrm{N} 14.47 / \mathrm{Kg}$. After washing, grinding and sieving (to $-75 \mu \mathrm{m}$ ) of the glass wastes, the cost rose to $\mathrm{N} 23.78 / \mathrm{Kg}$ for WG powder. The clay obtained which was sundried for 3 days was broken into lumps, milled and sieved to $-150 \mu \mathrm{m}$; while the WSD was sundried and sieved to $-850 \mu \mathrm{m}$. Samples were prepared by the mixing of WG at varied proportions of $10 \%, 15 \%$, $20 \%, 25 \%, 30 \%, 35 \%$ and $40 \%$ by weight WSD at $5 \%$ fixed amount and Clay, 
with water to clay ratio of 0.62 to 0.71 . Control samples were prepared by adding water to clay and the slurry extruded into cube moulds of dimension; $100 \mathrm{~mm} \times$ $100 \mathrm{~mm} \times 100 \mathrm{~mm}$ and $150 \mathrm{~mm} \times 150 \mathrm{~mm} \times 150 \mathrm{~mm}$ as per [32], cylindrical mould of upper and base diameter of $150 \mathrm{~mm}$ and height $300 \mathrm{~mm}$, cuboids moulds of $190 \mathrm{~mm} \times 90 \mathrm{~mm} \times 90 \mathrm{~mm}$ and $400 \mathrm{~mm} \times 100 \mathrm{~mm} \times 100 \mathrm{~mm}$. The slurry was compressed at $10 \mathrm{MPa}$ in the mould for compaction. The mix proportions are as indicated in Table 1.

Freshly prepared brick samples were left in the open atmosphere for 12 hours to allow stability before being weighed and oven-dried at $110^{\circ} \mathrm{C}$ for 12 hours. Afterwards, the samples were fired in an oven at $10^{\circ} \mathrm{C} / \mathrm{min}$ until $1000^{\circ} \mathrm{C}$ was attained. Brick samples were soaked at that temperature for $150 \mathrm{~min}$, then allowed to cool in the furnace before being tested for apparent porosity, water absorption, water absorption capacity, weight loss, volumetric shrinkage, saturation coefficient, initial suction rate, linear shrinkage, bulk density, compressive strength, wear rate, thermal conductivity. Durability tests were carried out by examining efflorescence and acid resistance (by weight loss in acid) using $1 \mathrm{M} \mathrm{H}_{2} \mathrm{SO}_{4}$. Chemical composition of materials used are presented in Table 2, just as standard procedure followed in testing samples are stated in Table 3.

\section{Results and Discussion}

Table 3 shows the values for the properties of each mix proportions, three samples representing each mix proportions were used for each test and the mean value obtained were recorded. From the results, the increasing proportions of additives led to reduction in the values of apparent porosity, water absorption, water absorption capacity, initial suction rate, linear shrinkage, weight loss and wear depth while there was an uptrend in bulk density, hardness, compressive strength, flexural strength, and thermal conductivity. In the case of efflorescence, the samples tested fell between slight and moderate which still met requirement for bricks [42] while weight loss in acid varied from one sample to another. Improved properties in the samples can be attributed to firing which enhanced

Table 1. Mix proportions of samples produced.

\begin{tabular}{cccc}
\hline Samples & Waste glass (\%) & Saw dust (\%) & Clay (\%) \\
\hline A & 0 & 0 & 100 \\
B & 10 & 5 & 85 \\
C & 15 & 5 & 80 \\
D & 20 & 5 & 75 \\
E & 25 & 5 & 70 \\
F & 30 & 5 & 65 \\
G & 35 & 5 & 60 \\
H & 40 & 5 & 55 \\
\hline
\end{tabular}


Table 2. Chemical composition of materials used.

\begin{tabular}{cccc}
\hline Compound & Clay (\%) & Waste glass (\%) & Saw dust (\%) \\
\hline $\mathrm{SiO}_{2}$ & 56.5 & 69.7 & 24.2 \\
$\mathrm{Al}_{2} \mathrm{O}_{3}$ & 18.7 & 3.1 & 16.5 \\
$\mathrm{Fe}_{2} \mathrm{O}_{3}$ & 7.2 & 0.2 & 1.7 \\
$\mathrm{MgO}$ & 1.2 & 1.9 & 2.5 \\
$\mathrm{CaO}$ & 1.8 & 9.5 & 33.3 \\
$\mathrm{~K}$ & $\mathrm{~N} \mathrm{O}$ & 0.8 & 2.7 \\
$\mathrm{Na}$ & 0.3 & 10.1 & 1.2 \\
$\mathrm{MnO}$ & 0.7 & 0 & 2.3 \\
Other oxides & 7.9 & 4.0 & 3.5 \\
LOI & 5.7 & 0.7 & 12.2 \\
\hline
\end{tabular}

LOI: Loss on Ignition.

Table 3. Test methods and standard procedures adopted.

\begin{tabular}{cc}
\hline Test for & Standard Procedure \\
\hline Porosity & {$[33]$} \\
Water Absorption (24 hrs immersion) & {$[33][34]$} \\
Water absorption (5 hrs boiling) & {$[33]$} \\
Saturation Coefficient & {$[35]$} \\
Initial Suction Rate & {$[35]$} \\
Linear Shrinkage & {$[36]$} \\
Bulk Density & {$[33]$} \\
Compressive Strength & {$[37]$} \\
Flexural Strength & {$[38]$} \\
Wear rate & {$[39][40]$} \\
Thermal Conductivity & {$[41]$} \\
Efflorescence & {$[42]$} \\
Weight loss & {$[35]$} \\
Volumetric shrinkage & {$[35]$} \\
Water absorption capacity coefficient & {$[43]$} \\
Acid resistance test (\% weight loss) & {$[44]$} \\
\hline
\end{tabular}

compaction and densification. In addition to this, additional silica content inclusion in fired brick samples as a result of higher silica content in WG (69.7\%) may be contributory to improved performance.

\subsection{Values of Properties obtained during Tests}

The test values of the properties obtained are as recorded in Table 4. 
Table 4. Values of properties evaluated at constant 5\% wt of wood saw dust.

\begin{tabular}{|c|c|c|c|c|c|c|c|c|}
\hline Properties & 0 & 10 & 15 & 20 & 25 & 30 & 35 & 40 \\
\hline Linear shrinkage & 9.5 & 8.9 & 6.4 & 5.5 & 7.3 & 5.4 & 5.3 & 5.1 \\
\hline Volumetric shrinkage & 6.78 & 6.70 & 6.40 & 4.20 & 4.10 & 3.88 & 3.62 & 3.91 \\
\hline Weight loss index & 8.33 & 6.54 & 5.71 & 6.11 & 4.43 & 5.81 & 3.33 & 3.21 \\
\hline Porosity & 36.6 & 36.9 & 33.3 & 30.2 & 26.3 & 22.9 & 19.2 & 15.6 \\
\hline Water absorption $24 \mathrm{hrs}$ & 25.2 & 24.5 & 22.1 & 20.7 & 18.4 & 15.8 & 15.8 & 14.4 \\
\hline Water absorption 5 hrs boiling & 26.0 & 27.8 & 24.0 & 23.8 & 19.8 & 16.0 & 14.5 & 15.6 \\
\hline Saturation coefficient & 0.97 & 0.88 & 0.92 & 0.87 & 0.93 & 0.99 & 0.99 & 0.87 \\
\hline Initial rate of water absorption & 2.4 & 2.4 & 2.3 & 2.1 & 1.9 & 1.8 & 1.7 & 2.1 \\
\hline Wear depth & 3.51 & 3.22 & 3.13 & 2.23 & 1.72 & 1.51 & 1.36 & 1.25 \\
\hline Bulk density & 1.48 & 1.53 & 1.64 & 1.73 & 1.86 & 1.92 & 1.98 & 2.02 \\
\hline Thermal conductivity (W/mK) & 0.21 & 0.21 & 0.24 & 0.27 & 0.32 & 0.39 & 0.43 & 0.46 \\
\hline Compressive strength & 11.8 & 12.1 & 13.5 & 15.4 & 17.5 & 19.7 & 21.3 & 22.5 \\
\hline Flexural strength & 1.84 & 1.95 & 1.96 & 2.64 & 3.30 & 4.32 & 3.72 & 3.35 \\
\hline Efflorescence (\%) & $\begin{array}{c}42 \\
\text { moderate }\end{array}$ & $\begin{array}{c}39 \\
\text { moderate }\end{array}$ & $\begin{array}{c}40 \\
\text { moderate }\end{array}$ & $\begin{array}{c}28 \\
\text { moderate }\end{array}$ & $\begin{array}{c}33 \\
\text { moderate }\end{array}$ & $\begin{array}{c}32 \\
\text { moderate }\end{array}$ & $\begin{array}{c}15 \\
\text { moderate }\end{array}$ & $\begin{array}{c}18 \\
\text { moderate }\end{array}$ \\
\hline $\begin{array}{l}\text { Water absorption capacity coefficient } \\
\qquad\left(\mathrm{Kg} / \mathrm{m}^{2} \mathrm{t}^{1 / 2}\right)\end{array}$ & 12.3 & 9.4 & 8.7 & 8.5 & 6.5 & 5.3 & 4.4 & 3.5 \\
\hline Acid resistance test (\%) & 5.1 & 5.3 & 4.7 & 3.4 & 3.8 & 3.2 & 3.2 & 2.9 \\
\hline
\end{tabular}

\subsection{Obtaining the Standard Values for Properties of Masonry Brick}

The standard values of the properties of masonry bricks are as recorded in Table 5 .

\subsection{Property Evaluation of Samples}

Sequel to the documentation of the values of properties for each sample, values recorded were compared with standard values adopted in this study, as stated in Table 5. The value for each sample in Table 4 was compared with the standard value for each property in Table 6 . Where the property value in Table 4 met the standard value in Table 5, 1 was recorded for such property under each sample in Table 6. Where the value failed to meet the required standard, 0 was recorded. In Table 6 for instance, comparing the apparent porosity value for sample A to $\mathrm{H}$ in Table 4 with the standard value of $<30 \%$ in Table 5, samples $\mathrm{E}$ (25\% WG), F (30\% WG), G (35\% WG), and H (40\% WG) had below BS 3921 [47] value of $30 \% .1$ was used for porosity under sample, E, F, G and $\mathrm{H}$ while in the case of other samples which failed to meet the standard value (i.e. have above 30\%), 0 was recorded, as represented under samples A, B, C and D, in Table 6. This procedure was followed for all samples until Table 6 was complete. At the end, the numbers were added and total value of index was obtained for each mix proportion/sample. 
Table 5. Standard values for properties of masonry bricks adopted in this study.

\begin{tabular}{ccc}
\hline Properties & Standard Value & Source \\
\hline Linear Shrinkage & Less than $8 \%$ & {$[45]$} \\
Volumetric Shrinkage & Less than $8 \%$ & {$[45]$} \\
Bulk density & $1.6 \mathrm{~g} / \mathrm{cm}^{3}$ & {$[46]$} \\
Apparent Porosity & Less than $30 \%$ & {$[47]$} \\
Water absorption (24 hrs immersion) & Less than $20 \%$ & {$[48][49]$} \\
Water absorption (5 hrs boiling) & Less than $25 \%$ & {$[48]$} \\
Saturation Coefficient & Less than 0.9 for normal weather & {$[48]$} \\
Weight loss & Less than $15 \%$ & {$[50]$} \\
Efflorescence & $0-50 \%$ & {$[42]$} \\
Initial Suction Rate & Between 0.25 to $1.5 \mathrm{Kg} / \mathrm{m}^{2} \cdot \mathrm{min}$ & {$[47]$} \\
Compressive Strength & Greater than $5 \mathrm{MPa}(\mathrm{low} \mathrm{rise} \mathrm{building})$ & {$[47]$} \\
Thermal conductivity & Not greater than $0.6 \mathrm{~W} / \mathrm{mK}$ & {$[41]$} \\
Flexural Strength & $2 \mathrm{MPa}$ & {$[51]$} \\
Wear rate & $3 \mathrm{~mm}$ & {$[52]$} \\
Water absorption capacity coefficient & $\leq 10 \mathrm{~kg} / \mathrm{min}^{2} \cdot \mathrm{t}^{1 / 2}$ & {$[43]$} \\
Acid resistance test & $\leq 4 \%$ & {$[44]$} \\
\hline
\end{tabular}

Table 6. Values of properties for samples with $5 \mathrm{wt} \%$ WSD.

\begin{tabular}{|c|c|c|c|c|c|c|c|c|}
\hline Properties & 0 & 10 & 15 & 20 & 25 & 30 & 35 & 40 \\
\hline Linear shrinkage & 1 & 1 & 1 & 1 & 1 & 1 & 1 & 1 \\
\hline Volumetric shrinkage & 1 & 1 & 1 & 1 & 1 & 1 & 1 & 1 \\
\hline Weight loss index & 1 & 1 & 1 & 1 & 1 & 1 & 1 & 1 \\
\hline Apparent porosity & 0 & 0 & 0 & 0 & 1 & 1 & 1 & 1 \\
\hline Water absorption $24 \mathrm{hrs}$ & 0 & 0 & 0 & 1 & 1 & 1 & 1 & 1 \\
\hline Water absorption $5 \mathrm{hrs}$ boiling & 0 & 0 & 1 & 1 & 1 & 1 & 1 & 1 \\
\hline Saturation coefficient & 0 & 1 & 0 & 1 & 0 & 0 & 0 & 1 \\
\hline Initial rate of suction & 1 & 1 & 1 & 1 & 1 & 1 & 1 & 1 \\
\hline Wear depth & 0 & 0 & 0 & 1 & 1 & 1 & 1 & 1 \\
\hline Bulk density & 0 & 0 & 1 & 1 & 1 & 1 & 1 & 1 \\
\hline Thermal conductivity $(\mathrm{W} / \mathrm{mK})$ & 1 & 1 & 1 & 1 & 1 & 1 & 1 & 1 \\
\hline Compressive strength & 1 & 1 & 1 & 1 & 1 & 1 & 1 & 1 \\
\hline Flexural strength & 0 & 0 & 0 & 1 & 1 & 1 & 1 & 1 \\
\hline Efflorescence (\%) & 1 & 1 & 1 & 1 & 1 & 1 & 1 & 1 \\
\hline Water absorption capacity coefficient & 0 & 1 & 1 & 1 & 1 & 1 & 1 & 1 \\
\hline Acid resistance test & 0 & 0 & 0 & 1 & 1 & 1 & 1 & 1 \\
\hline Total value & 7 & 9 & 10 & 15 & 15 & 15 & 15 & 16 \\
\hline
\end{tabular}




\subsection{Evaluating the Compliance Index for Each Sample}

Compliance Level/index

Compliance Index (C.I) for each sample was evaluated using Equation (1)

$$
\text { C.I }=\frac{\text { Total Value for each sample }}{\text { Total expected Value }} \times 100
$$

Total expected value refers to total number of standards adopted in this study, which are 16. Table 7 indicates that with appreciable increase in WG content, properties were improved leading to higher level of compliance.

\subsection{Evaluating Experimental Cost of Each Sample}

Cost Analysis: Going by percentage weight composition as stated in Table 1, cost was analysed in Table 8 and Table 9.

Table 7. Compliance level for each sample.

\begin{tabular}{ccccccccc}
\hline Samples & A & B & C & D & E & F & G & H \\
\hline WG (\%) & 0 & 10 & 15 & 20 & 25 & 30 & 35 & 40 \\
Compliance level (\%) & 44 & 56 & 63 & 94 & 94 & 94 & 94 & 100 \\
\hline
\end{tabular}

Table 8. Cost of each composition in each sample.

\begin{tabular}{ccccc}
\hline Samples & Clay (g) & WSD (g) & WG (g) & Cost of composition (Naira) \\
\hline A & 10.16 & 0 & 0 & 10.16 \\
B & 8.63 & 0.14 & 3.57 & 12.34 \\
C & 8.00 & 0.14 & 5.35 & 13.49 \\
D & 7.50 & 0.14 & 7.13 & 14.77 \\
E & 7.00 & 0.14 & 8.92 & 16.06 \\
F & 6.50 & 0.14 & 10.7 & 17.34 \\
G & 6.00 & 0.14 & 12.45 & 18.59 \\
H & 5.50 & 0.14 & 14.27 & 19.91 \\
\hline
\end{tabular}

Table 9. Summary of cost.

\begin{tabular}{cccc}
\hline Samples & $\begin{array}{c}\text { Cost of Composition } \\
(\mathrm{N})\end{array}$ & Fixed Cost (N) & $\begin{array}{c}\text { Experimental cost of } \\
\text { each sample (N) }\end{array}$ \\
\hline A & 10.16 & 67.40 & 77.56 \\
B & 12.34 & 67.40 & 79.74 \\
C & 13.49 & 67.40 & 80.89 \\
D & 14.77 & 67.40 & 82.17 \\
E & 16.06 & 67.40 & 83.46 \\
F & 17.34 & 67.40 & 84.74 \\
G & 18.59 & 67.40 & 85.99 \\
H & 19.91 & 67.40 & 87.31 \\
\hline
\end{tabular}


The cost of each sample was evaluated for clay as $\mathrm{N} 6.77 / \mathrm{Kg}$, for WSD as $\mathrm{N}$ $1.87 / \mathrm{kg}$ and WG (particles) as N 23.78/kg. Labour cost of crushing, milling and sieving was estimated as $\mathrm{N}$ 8377, for the 412 bricks produced, while $\mathrm{N} 19,391$ was also estimated for cost of firing which were fixed cost. Fixed cost amounts to N 67.40/sample.

It should however be noted that the cost analysis done in this study was evaluated based on the cost incurred in the course of the research which is dependent on the cost of materials used as at the time of study. This may not be a true representation of actual cost at the industrial scale. Also, Nigerian Naira (N) was employed in evaluating cost of materials and experimental cost of samples, since the study was done in Nigeria and the materials used were priced using the Naira (as at the time 1 US dollar was N 360 officially).

\subsection{Obtaining the Cost Ratio CR for Each Composition and Total Cost Ratio (TCR) of Each Sample}

Cost Ratio (CR) Analysis

Cost ratio is the ratio of cost on each component in each sample to the cost expended on the materials.

$$
\text { Cost Ratio }=\frac{\text { Cost on each component in each sample }}{\text { cost expended on all components in each sample }}
$$

\subsection{Compliance to Cost Ratio (C-CR)}

C-CR for each sample was evaluated using Equation (3)

$$
\mathrm{C}-\mathrm{CR}=\frac{\text { Compliance }}{\text { Total Cost Ratio }}
$$

\subsection{Plotting the TCR and C-CR Curve}

Total Cost Ratio (TCR)

From Table 10, it can be observed that cost ratio continues to rise from sample A (with no additives) to sample $\mathrm{H}$ (40\% WG and 5\% WSD). This implies that as

Table 10. Total cost ratio analysis.

\begin{tabular}{ccccc}
\hline \multicolumn{5}{c}{ Cost ratio of each component in each sample } \\
\hline Samples & Clay & WSD & WG & Total CR \\
\hline A & 0.0828 & 0 & 0 & 0.0828 \\
B & 0.0704 & 0.0011 & 0.0291 & 0.1006 \\
C & 0.0652 & 0.0011 & 0.0435 & 0.1089 \\
D & 0.0611 & 0.0011 & 0.0581 & 0.1203 \\
E & 0.0571 & 0.0011 & 0.0727 & 0.1309 \\
F & 0.0530 & 0.0011 & 0.0872 & 0.1413 \\
G & 0.0489 & 0.0011 & 0.1015 & 0.1515 \\
H & 0.0448 & 0.0011 & 0.1163 & 0.1622 \\
\hline
\end{tabular}


additives increase in the samples, cost of production continued to rise.

From Table 11 and Figure 1, sample H (40\% WG and 5\% WSD content) which had $100 \%$ compliance has a lower C-CR value compared to sample D (20\% WG and 5\% WSD) which has the highest C-CR value of 7.81 despite its lower compliance level of $94 \%$. Hence, it's more economical to employ sample D in masonry/construction than sample H. Sample D has the highest C-CR of all samples analyzed in this study, indicating that it will be the most cost-effective, with optimum impact in service. Therefore, sample with $5 \mathrm{wt} \% \mathrm{WSD}, 20 \mathrm{wt} \% \mathrm{WG}$ and $75 \mathrm{wt} \%$ Clay (Ijapo clay) is the optimum mix.

\subsection{Scanning Electron Microscopy (SEM)}

Figure 2(a) shows the SEM image of sample A with no additives. The image shows a large amount of pores while Figure 2(b) shows the image of selected sample D (5\% WSD and 20\% WG) having reduced pore volume compared to sample A ( $0 \%$ WSD and $0 \%$ WG content), which explains better property behavior in $20 \%$ WG content than in sample A with $0 \%$ WG. Reduction in pores is attributable to vitrification at high temperature leading to enhanced compaction.

Glass luster can be noticed in Figure 2(b) which is linked to the glassy phase formed at high temperature, filling up pores at high temperature. This further contributed to reduced porosity and better performance.

Table 11. Compliance to Cost Ratio (C-CR) Table.

\begin{tabular}{cccc}
\hline \multicolumn{4}{c}{ Compliance to Cost Ratio (C-CR) } \\
\hline Sample & Compliance (\%) & Total Cost Ratio & C-CR \\
\hline A & 44 & 0.0828 & 5.31 \\
B & 56 & 0.1006 & 5.57 \\
C & 63 & 0.1098 & 5.73 \\
D & 94 & 0.1203 & 7.81 \\
E & 94 & 0.1309 & 7.18 \\
F & 94 & 0.1413 & 6.65 \\
G & 94 & 0.1515 & 6.20 \\
H & 100 & 0.1622 & 5.80
\end{tabular}

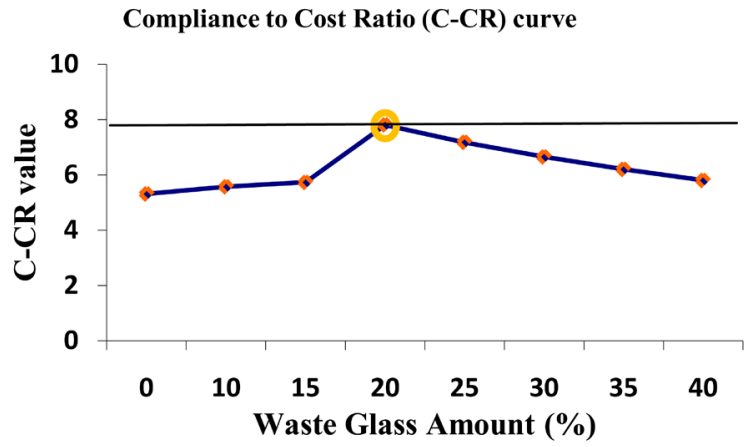

Figure 1. Compliance to cost ratio curve. 


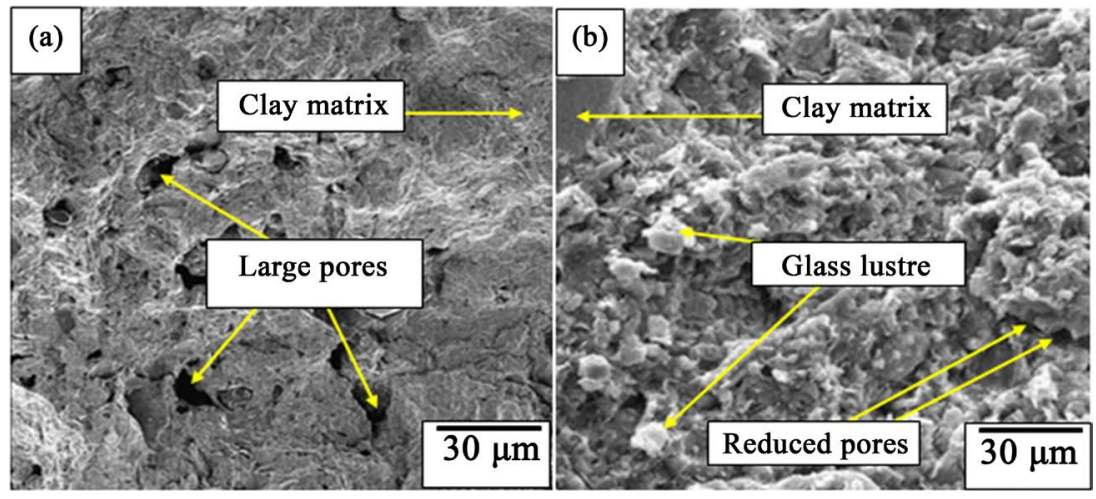

Figure 2. Images of the surface morphology of sample A (a) and Sample D (b).

\section{Conclusion}

The work has shown that the addition of wood saw dust and waste glass in the appropriate proportions could influence the mechanical and thermal properties of clay bricks for masonry. The work further revealed the appropriate techniques via which the bricks could be produced at the optimum cost possible. The scanning electron microscopy clearly revealed the influence of waste glass on the porosity (decrease) and the strength (increase) of the fired bricks. Compliance to Cost ratio gave a maximum value of 7.81 as obtained for sample D (20\% by weight WG and $5 \%$ by weight WSD). Therefore, $20 \%$ waste glass and $5 \%$ wood saw dust addition to fired bricks is expected to be most appropriate for construction of houses. It is therefore recommended for masonry.

\section{Acknowledgements}

The authors wish to express profound gratitude to the following bodies for their support for the research work: The Federal University of Technology, Akure (FUTA), Department of Metallurgical and Materials Engineering, FUTA and God Foundation Club of Akure, Nigeria.

\section{Conflicts of Interest}

The authors declare no conflicts of interest regarding the publication of this paper.

\section{References}

[1] Taiwo, O., Yusoff, N., Aziz, N. and Baba, A. (2017) Unleashing the Potencials of Housing Sector in Nigeria as Perceived by Users. International Journal of Built Environment and Sustainability, 4, 172-179. https://doi.org/10.11113/ijbes.v4.n3.210

[2] Vivian, E.L., Blamah, N.V., Tagwi, M.U. and Ezemokwe, I.U. (2012) An Assessment of Govertment Intervention in Urrban Housing Development in Nigeria. International Scientific Research Journal, 1, 34-41.

[3] Liu, H.Y. (1998) Government Intervention and Performance of Housing Sector in Urban China. Journal of the Asian Real Estate Society, 1, 127-149.

[4] Lin, Y.C., et al. (2018) Migration on Urban Housing Prices: Evidence from China's 
Majour Cities. Sustainability, 10, 3169. https://doi.org/10.3390/su10093169

[5] Ejaro, S. and Abubakar, A. (2013) Impact of Rapid Urbanization on Sustainability Development of Nyanya, Federal Capital Territory, Abuja, Nigeria. Journal of Social Science and Management, 3, 31-44. https://doi.org/10.4314/jasem.v17i2.13

[6] Fingleton, B. (2008) Housing Supply, Housing Demand and Affordability. Urban Studies Journal, 45, 1545-1563. https://doi.org/10.1177/0042098008091490

[7] Akanni, P.O., Oke A.E. and Omotilewa, O.J. (2014) Implications of Rising Cost of Building Materials in Lagos state, Nigeria. SAGE Open, 4, 1-7. https://doi.org/10.1177/2158244014561213

[8] Paulinus, I. (2015) Building Materials Costs Increases and Sustainability in Real Estate Development in Nigeria. African Journal of Economic and Sustainable Development, 4, 218-233. https://doi.org/10.1504/AJESD.2015.071907

[9] Iwuagwu, U. and Iwuagwu, B. (2015) Local Building Materials: Affordable Strategy for Housing the Urban Poor in Nigeria. Procedia Engineering, 118, 42-49.

https://doi.org/10.1016/j.proeng.2015.08.402

[10] Valasco, P., Morales, M.P. and Giro, M.A. (2014) Fired Clay Bricks Manufacturing by Adding Waste as Sustainable Construction Material-A Review. Journal of Construction and Building Materials, 63, 97-107. https://doi.org/10.1016/j.conbuildmat.2014.03.045

[11] Sakir, A., Naganathan, S. and Mustapha, K.N. (2013) Development of Bricks from Waste Material: A Review Paper. Australian Journal of Basic and Applied Sciences, 7, 812-818.

[12] Vijayaraghavan, C., Jijo, J. and Marithangam, S. (2009) Effective Bricks in Construction: A Performance Study. International Journal of Applied Engineering Research, 4, 327-334.

[13] Viruthagiri, G., Nareshananda, S. and Shanmugam, N. (2011) Analysis of Insulating Fire Bricks from Mixtures of Clays with Sawdust Addition. Indian Journal of Applied Research, 3, 469-473. https://doi.org/10.15373/2249555X/JUNE2013/157

[14] Elinwa, A. (2006) Effect of Addition of Sawdust Ash to Clay Bricks. Civil Engineering and Environmental Systems, 23, 263-270.

https://doi.org/10.1080/10286600600763149

[15] Fernando, P.R., Kannangara, G.L., Buddhika, G.P. and Urushiya, A. (2018) Synthesis and Characterization of Sustainable Man-Made Low Cost Clay Bricks with Bamboo Leaf Ash. Engineering Physics, 2, 15-22. https://doi.org/10.11648/j.ep.20180201.14

[16] Sutas J., Mana, A. and Pitak, L. (2012) Effect of Rice Husk and Rice Husk Ash to Properties of Bricks. Procedia Engineering, 32, 1061-1067.

https://doi.org/10.1016/j.proeng.2012.02.055

[17] Phonphuak, N. and Thiansem, S. (2012) Using Charcoal to Increase Properties and Durability of Fired Test Briquettes. Journal of Construction and Building Materials, 29, 612-618. https://doi.org/10.1016/j.conbuildmat.2011.11.018

[18] Aeslina, A.K., Nurul, S.A., Noor, A.S., Nur, A.I. and Mohd, M.A. (2017) Properties of Fired Clay Brick Incorporating with Sewage Sludge Waste. AIP Conference Proceedings, 1885, Article ID: 020150.

[19] Aeslina, A.K. and Ahmad, S.B.A. (2014) An Overview of Sludge Utilization into Fired Clay Brick. International Scholarly and Scientific Research and Innovative, 8 , 528.

[20] Chidiac, S.E. and Federico, L.M. (2007) Effects of Waste Glass Additions on the 
Properties and Durability of Fired Clay Brick. Canadian Journal of Civil Engineering, 34, 1458-1466. https://doi.org/10.1139/L07-120

[21] Demir, I. (2009) Reuse of Waste Glass in Building Brick Production. Waste Management \& Research, 27, 572-577. https://doi.org/10.1177/0734242X08096528

[22] Xu, L.L., et al. (2005) Study on Fired Bricks with Replacing Clay by Fly ash in High Volume Ratio. Journal of Construction and Building Materials, 19, 243-247. https://doi.org/10.1016/j.conbuildmat.2004.05.017

[23] Monteiro, S. and Vieira, C.M. (2014) On the Production of Fired Clay Bricks from Waste Materials: A Critical Update. Journal of Construction and Building Materials, 68, 599-610. https://doi.org/10.1016/j.conbuildmat.2014.07.006

[24] Obidiegwu, E., Esezobor, D., Agunsoye, J. and Lawal, G. (2015) Enhancement of Insulating Refractory Properties of Selected Nigerian Fire-Clays Using Coconut Shell. Journal of Minerals and Materials Characterization and Engineering, 3, 458-468. https://doi.org/10.4236/jmmce.2015.36048

[25] Folorunso, D.O. (2018) Characterization and Value Enhancement of Some Nigerian Refractory Materials for Thermal Insulation. Journal of Mechanical and Civil Engineering, 15, 79-86.

[26] Shado, A.S. (2015) Development and Characterisation of Rice Husk Insulating Bricks from Two Selected Deposits in Ekiti State, Nigeria. International Journal of Science and Research, 6, 132-138.

[27] Halima, C. and Bachir, C. (2013) Valorization of Wood Sawdust in Making Porous Clay Brick. Scientific Research Essay, 8, 609-614.

[28] Okunade, E. (2008) The Effect of Wood Ash and Sawdust Admixtures on the Engineering Properties of a Lateritic-Clay Brick. Journal of Applied Sciences, 8, 1042-1048. https://doi.org/10.3923/jas.2008.1042.1048

[29] Folorunso, D.O., Aramide, F.O., Olubambi, P. and Borode, J.O. (2015) The Effects of Firing Temperatures on the Performance of Insulating Firebricks Containing Different Proportions of Alumina and Sawdust. Journal of Minerals and Materials Characterization and Engineering, 3, 309-317. https://doi.org/10.4236/jmmce.2015.34033

[30] Hisham, H.A. and Samir, M.S. (2017) Properties of Fired Clay Bricks Mixed with Waste Glass. Scientific Research and Reports, 13, 1-9. https://doi.org/10.9734/JSRR/2017/32174

[31] Akinwande, A.A. (2020) Effects of Glass Waste Particles and Wood Saw Dust Admixture on the Properties of Fired Clay Bricks. M. Engr Thesis, Federal University of Technology, Akure.

[32] IS 516-1959. Method of Test for Strength of Concrete. Bureau of Indian Standards. Manak Bhavan, 9 Bahadur Shah Zafar Marg, New Delhi.

[33] ASTM 293-14a (2014) Standard Test Methods for Water Absorption, Bulk Density, Apparent Porosity and Apparent Specific Gravity of Fired Whiteware Products, Ceramic Tiles and Glass Tiles. ASTM International, West Conshohocken.

[34] IS 3495-1992, Part 2. Method of Test of Burnt Clay Building Bricks: Part 2, Determination of Water Aborption. Bureau of Indian Standards. Manak Bhavan, 9 Bahadur Shah Zafar Marg, New Delhi.

[35] ASTM C67/C67M-20 (2020) Standard Test Methods for Sampling and Testing Brick and Structural Clay Tile. ASTM International, West Conshohocken.

[36] ASTM C326-09 (2018) Standard Test Methods for Drying and Firing Shrinkages of Ceramic Whiteware Clays. ASTM International, West Conshohocken. 
[37] ASTM C1314-18 (2018) Standard Test Methods Compressive Strength of Masonry Prism. ASTM International, West Conshohocken.

[38] ASTM C293/C293M-16 (2016) Standard Test Methods for Flexural Strength of Concrete (Using Simple Beam with Center-Point Loading). ASTM International, West Conshohocken.

[39] ASTM C704/C704M-15e1 (2015) Standard Test Methods for Abrasion Resistance of Refractory Materials at Room Temperature. ASTM International, West Conshohocken.

[40] IS 13801-1993 (1993) India Standard, "Method of Determination of Resistance to Wear," Bureau of Indian Standards. Manak Bhavan, 9 Bahadur Shah Zafar Marg, New Delhi.

[41] ASTM C177-19 (2019) Standard Test Methods for Steady-State Heat Flux Measurements and Thermal Transmission Properties by Means of the Guarded-HotPlate Apparatus. ASTM International, West Conshohocken.

[42] IS 3495-1992, Part 3. Method of Test of Burnt Clay Building Bricks: Part 3, Determination of Efflorescence. Bureau of Indian Standards. Manak Bhavan, 9 Bahadur Shah Zafar Marg, New Delhi.

[43] Barbora, M., Otcouska, T. and Padevet, P. (2017) Water Absorption Capacity Coefficient and Mass Moisture of Rammed Earth Material. Acta Polytechnica CTU Proceedings, 13, 85-88. https://doi.org/10.14311/APP.2017.13.0085

[44] IS 4860 (1968) Method of Test for Acid-Resistant Bricks. Bureau of Indian Standards. Manak bhavan, 9 Bahadur Shah Zafar Marg, New Delhi.

[45] CNS 1127 (1999) China National Standard (CNS). Method of Test for General Types of Bricks for Building. CNS Catalog. R3042, Ceramic Industry, Pottery Wares. Bureau of Standards, Metrelogy and Inspection. Ministry of Economic Affairs, Republic of China.

[46] TCVN 1451:1998 (1988) Ministry of Construction Standard, "Solid Clay Bricks". Ministry of Construction, Hanoi.

[47] BS3921-1985 (1985) British Standard Specification. Standard Specification for Clay Bricks. British Standard Group. United Kingdom. 1985.

[48] ASTM C62-04 (2004) American Standard of Testing and Materials. Standard Specification for Building Brick (Solid Masonry Units Made from Clay or Shale). ASTM International, West Conshohocken.

[49] SNI 15-2094-2000 (2000) Indonesia Standard. Massive Red Bricks for Masonry Works. National Standardization Agency of Indonesia.

[50] TS 704 (1979) Turkish Standard for Clay Bricks. Turkish Standard Institution, Ankara.

[51] AS3700 (2001) Australian Standard for Masonry Structures. Engineering Design of Earth Buildings. NSW, Sydney.

[52] TSE TS 2824 EN 1338 (2002) Turkish Standard Institute, "Concrete Paving Block: Requirement and Test Methods". Ankara TSE. Turkey. 